\title{
ARTICLES
}

KAROL MUSZYŃSKI*

University of Warsaw

https://doi.org/10.26485/PS/2018/67.3/1

\section{LABOR LAW VIOLATIONS AS INNOVATIONS IN CENTRAL EASTERN EUROPEAN COUNTRIES ${ }^{1}$}

\begin{abstract}
The paper analyses secondary data from Czech, Hungarian, Polish, and Slovak (Central Eastern European Countries - CEECs) labor inspectorate reports to argue that the prevalence and patterns of labor law violations should be understood as a result of adaptations/innovations undertaken by firms in CEECs that use them to strategically lower labor law costs and make employment conditions more flexible. The paper is informed by dependent market economy theory from the varieties of capitalism approach. The main comparative advantage of dependent market economies lies in low labor costs. The spread and pattern of violations suggest that firms use labor law violations in a creative way to enhance their competitive advantage. It is enabled by an ineffective labor standards monitoring system. The possibility to circumvent and violate specific employment regulations to lower labor costs should be treated as an element of the institutional comparative advantage of CEECs.
\end{abstract}

* Assistant professor at the Faculty of Law and Administration; e-mail:k.muszynski@wpia.uw.edu.pl

1 This paper was written as a part of the project "Polityka prawa pracy po początku kryzysu ekonomicznego w Polsce. Segmentacja rynku pracy i naruszenia prawa pracy" [Labor law policy after the economic crisis in Poland. Labor market segmentation and labor law violations], funded by the (Polish) National Science Centre on the basis of decision number UMO-2015/19/N/HS5/01227. 
The paper also suggests that governments in CEECs partially promote labor law violations through "drift policies".

Keywords: labor law violations, dependent market economy, varieties of capitalism, innovation, Central and Eastern Europe

\section{INTRODUCTION}

Data on labor law violations among Central Eastern European Countries [CEECs] - Czechia, Hungary, Poland, and Slovakia - indicate a widespread problem. In 2016, the Czech Labor Inspectorate discovered no fewer than 35,600 infringements in ca. 29,500 firms [SUIP 2017b: 47-51]2, while their Slovak counterpart discovered 42,000 violations in ca. 28,000 firms [NIP 2017: 4]. Polish inspectors found over 80,000 infringements in 68,000 firms [PIP 2017: 183]. The Hungarian Labor Inspectorate audited almost 18,000 employers and found ca. 13,500 of them in violation of some labor law provisions, with $68 \%$ of workers of those enterprises being affected [NGM 2017a: 1]. The data show that many employers avoid paying taxes and social security contributions, deprive employees of their overtime pay, and force them to work in unlawful conditions or on illegal types of contracts, etc. Why are violations so common and do they present any similarities? Moreover, how can this problem, given its extent, be reconciled with the fact that CEECs enjoy relatively decent economic development, and are sometimes even viewed as examples of economic success?

This paper will try to approach this issue by applying conceptual tools derived from a varieties of capitalism (VoC) approach to institutions and institutional adaptations. $\mathrm{VoC}$ is an approach in the comparative institutional analysis of capitalism that conceptualizes political economies as substantially different in terms of crucial elements of an institutional framework, with differences making them more efficient in a certain type of production ("institutional comparative advantage") [Hall, Soskice 2001]. The starting point of the VoC theory was a conceptual distinction of highly developed capitalist countries into liberal mar-

2 The Czech Labour Inspectorate (SUIP) report does not include any information on the overall number of infringements, and only provides data on the selected most common ones. I sent an official enquiry to SUIP asking for this data, but I did not receive an answer. Therefore, I have calculated the minimum number of infringements by summing up the numbers of the most common infringements provided in SUIP 2017b. The number of selected most common infringements comes out to exactly 35,600 ; thus, the total number of all infringements is probably much higher. 
ket economies (LMEs) and coordinated market economies (CMEs). In the VoC approach, Czechia, Hungary, Poland, and Slovakia are described as dependent market economies (DMEs) - with a comparative advantage of low labor costs that are specialized in the production of semi-standardized goods in the middle positions of the global value chain [Nölke, Vliegenthart 2009]. Characteristics of DMEs' institutional framework, such as their responsiveness to the needs of foreign investors, weak trade unions, specific elements of labor law etc., are said to influence this comparative advantage.

This paper will analyze secondary data from Czech, Hungarian, Polish, and Slovak labor inspectorate reports to argue that the prevalence of labor law violations should be understood as a result of adaptations undertaken by firms in CEECs, aimed at strategically lowering labor law costs and making employment regulations more flexible. Violations should be treated as the firms' innovative practices that are consistent with the comparative advantage of low labor costs and that enhance this advantage. Concurrently, the actual opportunity to violate or circumvent employment regulations constitutes an element of the institutional comparative advantage of those countries, which is even partially influenced by public policies.

By treating labor law infringements as innovative adaptations consistent with an institutional framework, the paper intends to fill some gaps that exist in the current state of the art in VoC theory on DME. First is the question of how market actors - as creative rule takers - can adapt the institutional framework. The VoC approach, in accordance with the standard neoinstitutionalist assumption, presupposes that actors engage in ongoing efforts to make better use of the rules that exist in their framework in order to improve production methods, products, and services, etc. [Streeck 2004]. I will call these efforts "innovative practices". Innovative practices remain in line with basic coordinating mechanisms in the economy or allow production to be more effective by resolving specific problems that emerge in those frameworks, thus making it possible to introduce economic innovations. Secondly, the paper will address the problem of how the institutional framework in DMEs may encourage market actors to engage in "innovative practices". Finally, the paper will analyze how rule makers (governments) in DMEs may conduct effective public policies, i.e., increase the effectiveness of the institutional framework. 


\section{THE VOC APPROACH AND LEVELS OF INSTITUTIONAL ANALYSIS - "SUPPLY", "DEMAND", AND "POLICY"}

The VoC approach assumes a complex relationship between the market actors' behaviors, the institutional framework, and governmental policies [Hall, Soskice 2001; Amable 2003]. It draws heavily from so-called contingency theories in industrial organization and sociology, where it is assumed that economic performance relies on efficient links between institutions, firms' strategies, and the technological features of production [Casper 2010: 342]. VoC assumes that distinct types of economies perform better when institutional elements are organized around a relatively consistent institutional logic [Deeg 2007]. It means that an institutional framework not only needs to support common practices developed by the market actors (most importantly firms), but also that the elements of this framework should be coherent to reinforce the production of specific types of products or services. Firms (and, subsequently, economies) perform better when they are able to introduce innovations, which are understood in the economic sense, in the Schumpeterian tradition [Schumpeter 1934], like new products or services, or improvements to existing methods of production - making production faster, cheaper, and more precise, etc. [Hall, Soskice 2001; Jackson, Deeg 2008]. Institutional frameworks create incentives for firms to engage in certain forms of activity, but to develop innovations and improve production, firms must engage institutions [Hall, Soskice 2001; Casper 2010; Kristensen, Zeitlin 2005]. Moreover, rule makers, due to the role of the economic system in modern society, in general, try to influence institutional frameworks to improve their efficiency. Hall and Soskice theorized that "economic policies will be effective only if they are incentive compatible, namely complementary to the coordinating capacities embedded in the existing political economy" [Hall, Soskice 2001: 46]. This means that policies need to consider not only the initial shape of the formal framework, but also the typical behaviors of the rule takers. Hall and Soskice's original introductory paper to "Varieties of Capitalism" is focused on the differences of CMEs' and LMEs' political economies and the fact that in CMEs governments have a more difficult job due to the fact that their comparative advantages are grounded on the informal adaptations undertaken by the actors. Still, these informal adaptations are believed to be made within the boundaries designated by the institutional framework. More specifically - actors are expected to act in accordance with the regulations and not violate or circumvent the rules, even when they adapt them.

To sum up, the effectiveness of an institutional framework depends on the rule takers/market actors continuously adapting the existing institutions for their 
benefit, undertaking innovative practices ("demand side") within the basic shape of formal institutions which should be coherent and create incentives for firms to engage in a certain type of activity ("supply side"), whereas an institutional framework can be influenced by rule makers to increase this coherence ("policy level"). The benchmark for economic performance is innovations, which are treated as a regular, patterned output, in fact, produced by firms. Understanding of innovation in $\mathrm{VoC}$ focuses on the interaction between the structured behaviors of enterprises and the institutional framework that is under governmental influence.

On the basis of these assumptions, Hall and Soskice clustered highly developed economies into LMEs and CMEs. Even though this approach is being questioned, criticized, and revisited, and alternative classifications have been developed [e.g., see: Amable 2003; Witt, Jackson 2016], this division remains the main point of reference in the field of comparative studies on capitalism. LMEs' performance depends on radical innovations, i.e., changes that involve substantial modifications in design or the production process, serving as the bases for completely new products or services, usually undertaken in sectors which can be changed faster and reinvented, e.g., in biotechnology, software, telecommunications, or services such as advertising and entertainment. On the supply side, this is achieved through, e.g., liberal employment relationships and a strict approach to anti-trust regulations. On the demand side, firms in the LME framework engage in "Williamsonian-type" innovative practices that intend to lower transaction costs and solve the problem of moral hazard, which is crucial for the production of radical innovations. For instance, firms may introduce compensation based on results to deal with the problem of workers undermining productivity growth in fear of being dismissed, or CEO mobility practice may emerge as a form of substitution for the absence of knowledge transference mechanisms between the firms [Lehrer 2001]. At the policy level, this means that in order to increase the effective functioning of the economic system, governments in LMEs have to implement "market incentive policies" [Hall, Soskice 2001: 47], i.e., undertake formal deregulation, give tax incentives, provide subsidies for $\mathrm{R} \& \mathrm{D}$, etc.

CMEs rely on incremental innovations, i.e., relatively minor improvements to existing products, services, and production processes, etc., which result in gradual growths in effectiveness or productivity. This is typical of sectors where consumer loyalty and/or backward compatibility play an important role, such as the industrial production of capital goods and consumer durables. On the supply side, this is achieved through the promotion of long-term investment in workers' skills and stable cooperation between contractors, which influences the shape of 
CMEs' framework, e.g., rigid labor law, more relaxed competition law, etc. On the demand side, firms engage in "Durkheimian-type" innovative practices that increase non-market coordination between the actors ${ }^{3}$. For instance, the introduction of seniority-based compensation schemes can increase workers' motivation to engage in the success of the firm. At the policy level, governments in CMEs aim at undertaking "coordination incentive policies" [Hall, Soskice 2001: 48] that revolve around the administration of self-regulation, and financial aid for VET schemes developed by employers and trade unions, etc.

\section{INTEGRATING THE "SUPPLY", "DEMAND", AND "POLICY" LEVEL OF ANALYSIS AND DME THEORY}

I will utilize the division between "supply", "demand", and "policy" level in the analysis of dependent capitalism. There have been many attempts to integrate CEECs into the VoC approach [for reviews see Bluhm 2010; Jasiecki 2013]. Recently, CEECs have been increasingly conceptualized as dependent market economies, comparatively advantaged in the assembly platform production of semi-standardized industrial goods in the global value chain [Nölke, Vliegenthart 2009; Drahokoupil 2009; Drahokoupil, Myant 2016]. It is theorized that their institutional comparative advantage lies in a mixture of favorable conditions for FDI and mechanisms allowing them to keep the labor costs of a relatively well-educated workforce low [Nölke, Vliegenthart 2009]. Multinationals are believed to play the key role in the development of capitalism, by providing financing to firms in CEECs, introducing production changes, as well as being the main point of reference for governments in drafting public policies [Drahokoupil 2009; Jasiecki 2014].

Due to the heavy focus on the role of multinationals, DME theory marginalized the relationship between firms' micro-strategies and the coherence of the institutional framework, as well as the role of governmental policies in this process. We know that, e.g., LMEs' institutional framework promotes "Williamsonian" actions that lower transaction costs and produce radical innovations, and "market incentive" policies that facilitate market balancing. It was unclear what types of firms' strategies are promoted by institutional frameworks in DMEs, and - what follows - how governments can implement policies to encourage firms to improve performance. Moreover, the concept of innovation was used only incidentally

3 The distinction between the Williamsonian and Durkheimian functions of institutions is after Wolfgang Streeck [2009]. 
in DME theory. The general assumption is that firms in DMEs do not produce innovations; they are transferred there by multinationals [e.g., Nölke, Vliegenthart 2009; Nölke 2011, Drahokoupil, Myant 2015]. By treating the original VoC approach more consistently, one can see that the concept of innovation is crucial for the whole VoC theory, as it is key to providing an answer to why particular economies perform better than others. As mentioned before, to increase economic performance, an institutional network has to provide both the general framework of operation for firms as well as the scope for innovative practices, such as institutional adaptations and creative uses, so that firms could introduce innovations in line with the principal logic of coordination. DME theorists have so far claimed that DMEs' institutional framework allows firms to use tax breaks and relatively lower labor costs for their benefit [e.g., Nölke, Vliegenthart 2009; Drahokoupil 2009], but they did not answer where market actors found space for adaptations compatible with DMEs' main competitive advantage of low labor costs.

DME theory should, therefore, be supplemented by the concept of innovative practices and innovation that would integrate three levels of analysis (what I call the "demand", "supply", and "policy" level). I must stress that this proposition should not be treated as competitive towards other interpretations created by DME theorists, but more as a complement allowing to better this theory to be integrated within the VoC field. My proposition is as follows: firms in DMEs focus their efforts on lowering labor costs, which constitute DMEs' main comparative advantage, with the use of circumventions and violations of employment regulations. These actions, which should be understood as specific types of innovative practices directed at lowering labor costs, are, in fact, facilitated and incentivized by the institutional framework and governmental policies. The proposition fills the gap in DME theory by providing micro-level foundations for understanding how enterprises can benefit from creatively engaging DMEs' institutional framework. It also makes it possible to explain how governments are able to target this mechanism and introduce economic policies that increase performance.

At the "demand level", firms' innovative practices focus on searching for a more optimized way to lower labor costs. This is achieved by what I call "Mertonian" actions, which consist of circumventing and violating an employment regulation that incurs costs borne by employers. I will show, based on the data gathered by labor inspections from Czechia, Hungary, Poland, and Slovakia, that violations in DMEs are not only extremely widespread, but that they are also almost solely cost-oriented. 
At the "supply level", an institutional framework allows and encourages firms to circumvent and violate employment regulations. An imprecise regulation intertwined with weak surveillance mechanisms, mostly ineffective and weak labor inspectorates, make it easy to strategically violate employment regulations, as economic gains are far bigger than potential sanctions. I will analyze sanctions levied by labor inspectorates in detail, as well as look at specific legal solutions adopted in DMEs to substantiate this claim.

At the "policy level", this means that in order to stimulate a country's comparative advantage, governments need to allow circumventions and violations to happen. This is undertaken in the form of reforms that undermine existing institutions or inactions - which I call "drift policy". I will look at particular policies adopted in DMEs to prove this.

TABLE 1. Varieties of capitalism and firms' innovative practices, institutional framework and public policies consistent with comparative advantage

\begin{tabular}{|l|l|l|l|}
\hline \multicolumn{1}{|c|}{ LME } & \multicolumn{1}{|c|}{ CME } & \multicolumn{1}{c|}{ DME } \\
\hline $\begin{array}{l}\text { Prevalent type } \\
\text { of innovation }\end{array}$ & $\begin{array}{l}\text { Radical } \\
\text { innovation }\end{array}$ & Incremental innovation & (Labor) cost innovation \\
\hline $\begin{array}{l}\text { Prevalent type of } \\
\text { innovative practices }\end{array}$ & $\begin{array}{l}\text { "Williamso- } \\
\text { nian" - lowe- } \\
\text { ring transaction } \\
\text { costs }\end{array}$ & $\begin{array}{l}\text { "Durkheimian" } \\
\text { - increasing confiden- } \\
\text { ce and long-term } \\
\text { cooperation }\end{array}$ & $\begin{array}{l}\text { "Mertonian"- exploitation } \\
\text { of gaps and loopholes to } \\
\text { lower costs }\end{array}$ \\
\hline $\begin{array}{l}\text { Example of firms" } \\
\text { innovative practices }\end{array}$ & $\begin{array}{l}\text { CEO mobility } \\
\text { - enables the } \\
\text { spread of know- } \\
\text { ledge }\end{array}$ & $\begin{array}{l}\text { Compensation based } \\
\text { on seniority schemes } \\
\text { - increases long-term } \\
\text { orientation of counter- } \\
\text { parties }\end{array}$ & $\begin{array}{l}\text { Using non-standard contracts } \\
\text { in place of standard ones } \\
\text { - lowers labor costs }\end{array}$ \\
\hline $\begin{array}{l}\text { Role of institutional } \\
\text { framework in incen- } \\
\text { tivizing innovative } \\
\text { practices }\end{array}$ & $\begin{array}{l}\text { Flexible regula- } \\
\text { tions allow for } \\
\text { fast reorganiza- } \\
\text { tions }\end{array}$ & $\begin{array}{l}\text { Strict regulations } \\
\text { extend time-orientation } \\
\text { and allow knowledge } \\
\text { to grow }\end{array}$ & $\begin{array}{l}\text { Imprecise regulation and } \\
\text { ineffective surveillance } \\
\text { allow circumventions } \\
\text { and violations }\end{array}$ \\
\hline $\begin{array}{l}\text { Effective public } \\
\text { policies }\end{array}$ & $\begin{array}{l}\text { Market-oriented } \\
\text { policies }\end{array}$ & $\begin{array}{l}\text { Coordination-oriented } \\
\text { policies }\end{array}$ & Drift policies \\
\hline $\begin{array}{l}\text { Example of effec- } \\
\text { tive public policy } \\
\text { with regard to } \\
\text { employment } \\
\text { regulations }\end{array}$ & $\begin{array}{l}\text { Deregulation / } \\
\text { flexibilization }\end{array}$ & $\begin{array}{l}\text { Strengthening em- } \\
\text { ployment protection / } \\
\text { increasing co-determi- } \\
\text { nation }\end{array}$ & $\begin{array}{l}\text { Undermining reforms } \\
\text { (e.g., extending possibilities } \\
\text { for using non-standard con- } \\
\text { tracts) or inaction } \\
\text { (lowering the effectiveness } \\
\text { of labor standard monitoring } \\
\text { systems) }\end{array}$ \\
\hline
\end{tabular}

Source: author's own elaboration 


\section{THE "DEMAND" LEVEL - VIOLATIONS AND CIRCUMVENTIONS AS INNOVATIVE PRACTICES}

Due to labor costs being DMEs' comparative advantage, firms' strategies concentrate on further labor cost reductions with the use of circumventions and violations of employment regulations. Employment regulations distribute costs and benefits between the employer and employee - it allows an employer to profit from an employees' work, but also protects the employee against the abuse of economic power. Labor law establishes a standard of protection for workers. It is, therefore, almost a tautology to say that infringing this standard allows for savings. Mechanisms such as minimum wage, sufficient rest time, and requirements to provide work clothing, etc., force the employer to interiorize certain economic risks and costs. Some labor law violations are, however, more financially oriented than others. Harassment is a violation of labor law that does not have an explicit financial aspect, even though it presents an example of an abuse of economic power. At the same time, violations such as infringing Occupational Health and Safety (OHS) requirements, minimum wage violations, depriving workers of overtime pay or using informal or non-standard contracts that involve lower taxes or social security contributions, are strictly financially oriented. In such cases, the employer gains an explicit economic advantage.

Following the distinction between LMEs' "Williamsonian" actions and CMEs" "Durkheimian" actions, I suggest calling strategies characteristic of the firms in a DME institutional framework "Mertonian". This refers to Robert K. Merton's [1968] idea of "innovation" as achieving socially approved goals with the use of unapproved means. It allows us to show that "Mertonian" adaptations in DMEs differ from their counterparts in LMEs and CMEs in that they infringe formal rules. It also plays very well with the fundamental problem that DMEs face, which will be further developed in the discussion - that their institutional advantage, in fact, partly relies on behaviour that, from a formal point of view, is deviant.

By analysing the secondary data from the 2016 labor inspection reports from CEECs, I distinguished four categories of the most common "Mertonian" adaptations in the field of employment regulation: the use of non-standard (including informal) forms of employment where standard contracts should be used; violations regarding wages; violations regarding working time; and infringements of $\mathrm{OHS}^{4}$. Using non-standard contracts, even when standard contracts are legally required, creates substantial savings for the employer, as the former are taxed at a lower rate,

\footnotetext{
4 The data is not always fully comparable, since it has been collected by different institutions.
} 
are outside minimum wage regulations, have shorter termination notice periods, and provide for the different distribution of OHS risks, etc. Violations regarding wages create direct financial profits, such as saving on overtime pay, paying less than the minimum wage, or often not paying at all. Not paying wages on time, an infringement widespread among CEECs, allows firms to enhance their shortterm liquidity by depriving workers of funds for some period. Forcing them to work beyond the statutory limitations enables employers to hire fewer workers and to decrease the overall level of employment. Manipulating work time records and not observing time limitations allows for a reduction in the costs of overtime wages or rest time. By lowering OHS standards below statutory requirements, employers avoid the necessity of incurring costs by increasing the risk that their workers are subject to. Hiring unqualified staff also allows them to limit wages, as workers that are trained to use specific machinery are obviously more expensive.

\section{The use of non-standard (including informal) employment where standard contracts should be used}

The incidence of informal employment among DMEs is at an average level ${ }^{5}$, but non-standard contracts are very common. Some practices aimed at using informal work have emerged, but non-standard formal contracts remain one of the main types of adaptive action. Specific forms vary in each country.

In Czechia, two distinct ways of circumventing labor law have emerged. The first is the use of bogus self-employment (švarcsystém). Czech solo self-employment stands at $15.5 \%$, and $9.6 \%$ for women [OECD 2017]. We lack up-to-date data, but a 2008 study found that from 13 to $26 \%$ of self-employment was bogus [Geissler 2012]. To avoid liability for the use of self-employment where standard contracts should have been concluded, employers often create "chains" of subcontractors. That results in a situation in which the bogus self-employed are often unaware of whom they are really working for [SUIP 2017a: 64; SUIP 2017c: 99]. Secondly, the posting of workers is creatively used to circumvent labor regulations in employment. Companies use posted workers hired formally by subcontractors in another country to provide temporary services, which enables them to use the more convenient labor regulations of the other country [SUIP 2017a: 74].

A similar solution with the fraudulent posting of workers is used in Slovakia [NIP 2017: 13]. Moreover, Slovak firms exploit a wide range of civil law con-

5 In 2013, in CEECs, the level of informal employment was comparable with the rest of the EU and stood at 3-5\%, with 3.75\% being the European average [Williams, Horodnic and Windebank 2015]. 
tracts in place of standard contracts for their own benefit [NIP 2017: 6], such as agreements to work up to 10 hours per week, agreements to perform specific work up to 350 hours in one year, and agreements to work up to 20 hours per week for students up to 26 years of age (dohody o prácach vykonávaných mimo pracovného pomeru). Before 2013, those contracts were extremely popular, with as much as of the population employed on them [Goliaš 2014]. They remain very popular, but their use has dropped by ca. $40 \%$ since reformed social and health contributions were equalized with labor code contracts in 2013 and minimum wage regulations were imposed on the contracts. Civil law employment is used mainly to circumvent more restrictive labor law employment and to lower labor costs [NIP 2017: 13].

In Poland, non-standard contracts used as substitutes for standard contracts are widespread [Kamińska, Lewandowski 2015; Muszyński 2016]. Poland is notorious for temporary contracts, with its $22 \%$ incidence being the highest among EU countries and almost twice the EU28 average [Eurostat 2017]. After the economic crisis, civil law contracts gained popularity as an alternative to labor code contracts due to lower taxes, limited social security contributions, and greater flexibility with regard to structuring the employment relationship and dismissal possibilities. Civil law workers are outside working time regulations, have limited OHS protection, and are deprived of the right to a coalition. Civil law contracts for a mandate (umowa-zlecenie) are partially included in the social security contributions and hourly minimum wage regulations, but this was reformed as late as 2015-2016. Another very popular contract, for a specific task (umowa $o$ dzieło), remains almost completely outside any regulations; workers lack not only working time and OHS protection, but they are also outside the statutory minimum wage, social security, and obligatory healthcare contributions. Those contracts are often concluded with individual self-employed people, who are very numerous in Poland - 17\% of men and 11\% of women are self-employed without employees, a percentage significantly higher than OECD average [OECD 2017]. From 1.1 to 1.4 million workers work solely on civil law contracts. Around $20-30 \%$ of those contracts are found to have been concluded in direct violation of the labor law, i.e., in a situation where a labor code contract should have been concluded [Muszyński 2016]. Moreover, in Poland, civil law contracts are very often used to structure the employment relationship with temporary work agencies. Around $50 \%$ of all temporary work agency workers are employed on civil law contracts, which represents an example of the peculiar multiplication of the use of non-standard legal solutions (non-standard work within a temporary work 
agency is structured with the use of a non-standard civil law contract). Secondly, Polish enterprises have also developed a specific practice that has enabled them to use informal work almost without liability. The employer has seven days to register a worker's contributions to the social security system. At the same time, until 2016, it was not obligatory to conclude a labor contract in writing - it was possible to conclude it orally. Therefore, it was common that employees were, in fact, working informally but if an audit appeared, the auditors were informed that the employee was at work for the first time and therefore the employer still had time to register the contract in the social security system. This allowed for the almost sanction-free use of informal workers, as it was possible to remedy such a violation within the course of one week by simply registering the worker in the social security system after a labor inspectorate audit had taken place and noted that the worker was not yet registered [PIP 2016: 137].

In Hungary, there are three main ways of circumventing standard labor contracts. The first involves the use of civil law contracts for services, with consequences and characteristics similar to the use of civil law contracts in Poland and Slovakia [Zaccaria 2015]. Secondly, an institution of simplified employment (egyszerüsitett foglalkoztatás) is used ${ }^{6}$. These contracts are outside the social security contribution system and provide very limited rights for workers. Employers are required to pay healthcare contributions and low taxes - a fixed rate of $500 \mathrm{HUF}$ (ca. 1.5 EUR) per day for seasonal work in agriculture or the tourist sector or 1000 HUF (ca. 3 EUR) for other casual work. Simplified employment is often used as a substitute for regular employment. However, simplified work can only be used by employers up to 120 days/year (in the case of work in agriculture/ tourism) or up to 90 days for other casual work. It is, therefore, also common that employees are reported only from time to time to circumvent time limits [NGM 2017a: 6]. Thirdly, Hungarian law, like Polish law until 2016, does not require parties to conclude contracts in writing, which has caused multiple innovative practices to emerge. For instance, workers without written contracts are often exchanged between employers and, in the process, the contract conditions are changed to the detriment of the worker [NGM 2017a: 7]. Simplified employment is very often not reported at all to circumvent taxes, especially since workers are often employed only for a short period, so employers hope to avoid being audited [NGM 2017a: 6].

6 Simplified employment has replaced the (in)famous employment on the basis of the socalled "blue" "Booklet for Casual Workers" in 2010. 


\section{Violations regarding wages}

Violations regarding wages consist of very diverse practices, such as minimum wage violations (the employer pays workers less than the required minimum wage); depriving workers of overtime pay or nightshift premiums; or not paying on time (the employer pays but much later than required).

In Czechia, the Labor Inspectorate detected ca. 3,000 violations regarding wages in 2016. Most common were not paying the wage at all, not observing the required level of salary, as well as a lack of overtime pay for weekend, night shifts, and overtime work [SUIP 2017a: 14]. Not paying a salary immediately after a contract is terminated is also a very common infringement [SUIP 2017c: 74]. In Slovakia, among the 12,000 infringements of personal labor law, the most popular were infringements such as minimum wage violations, not paying wages on time and not paying wages in general [NIP 2017: 6].

In Hungary and Poland, minimum wage violations are widespread - the incidence of workers receiving less than the minimum wage in 2012 stood at ca. $4 \%$ for Hungary and ca. $6 \%$ for Poland [EU-SILC after: Goraus-Tanska and Lewandowski 2016]. In Hungary, irregularities regarding wages affect $14 \%$ of workers, with the most common infringements being not paying on time, not paying for overtime work, and violating rules regarding settling wages [NGM 2017a: 10]. In 2016, in Poland, 23-25\% of enterprises infringed rules on equivalent pay for holiday work, while $18 \%$ avoided paying an additional wage for working night shift. Moreover, $17 \%$ had problems with paying wages on time, and $12 \%$ with paying wages in general [PIP 2017: 80]. 18\% of enterprises did not provide the severance payments required by law.

Moreover, there are certain practices that are probably - at least to some extent - tolerated by employees, namely envelope wages. They are widespread in CEECs, except for Czechia, which, with $3 \%$ of workers receiving envelope wages, ranks lower than the European Union average of 5\%. In Slovakia, 7\% of workers received envelope wages, in Hungary - 8\%, and in Poland - 11\% [Williams 2015].

\section{Violations regarding working time}

Problems in this category involve infringements regarding time-keeping documentation, breaks during work, or the observation of statutory daily and weekly minimum rest times.

In 2016, in Poland, ca. $32 \%$ of all audited enterprises had problems with keeping their time records properly, and $27 \%$ did not have the required internal regulations on working time. Violations regarding rest times were also widespread. 
$35 \%$ of enterprises did not provide sufficient days off work during the workweek, $15 \%$ did not observe the required daily rest period hours, and $13 \%$ - the weekly rest period [PIP 2017: 78]. In Hungary, violations involving working time affected around $1 / 4$ of workers. Most common were infringements regarding recording requirements, rest periods and overtime work limits [NGM 2017a: 8]. 22\% of workers in audited enterprises in Hungary were affected with irregularities related to work time recording or with a lack of registers. Defective or falsified registers were most common [NGM 2017b: 8-9]. Reportedly, many Hungarian employers keep two registers (one real and one fake for the sake of audits) which allows them to circumvent regulations without being in danger of being sanctioned for it [NGM 2017a: 9]. In both Czechia and Slovakia, infringements regarding keeping working time records constitute the third most common violation in the employment standard violations category [SUIP 2017a: 14; NIP 2017: 6].

The problem with working time is especially visible in the transportation sector. Drivers are forced to work over the limitations provided in statutory law, without rest periods and without proper breaks. For instance, in Poland in 2016, the provision that obliged employers to provide sufficient daily rest time was violated by $2 / 3$ of entities providing transportation services and affected $1 / 3$ of all drivers in the audited enterprises [PIP 2017: 82]. Meanwhile, the regulation limiting working time to 10 hours per day was violated by $2 / 3$ of employers and affected almost $1 / 2$ of all drivers [PIP 2017: 83]. In Slovakia, around $43 \%$ of all drivers in the audited enterprises did not observe the daily minimum rest time, and $40 \%$ exceeded the regulation limiting work without a break to 4.5 hours [NIP 2017: 7]. One should note that CEECs provide a substantial amount of transportation services in Europe. The low labor costs of drivers from CEECs is the main reason why they are slowly taking over transportation services in many Western European countries (for instance, Polish and Czech drivers now provide 20\% of all transportation services in Germany; the number is growing from year to year) [BAG 2017]. The fact that labor law violations are so widespread among them seems to play some role in that.

\section{Infringements of OHS standards and training requirements}

Employers in CEECs creatively approach regulations regarding workplace standards; machinery, tools, and working clothes; training, including OHS training; and the medical checkups of their employees.

Conducting operations in workplaces that lack the required permits is the most common OHS infringement in Slovakia [Table 2 in the attachment to NIP 
2017] and Czechia [SUIP 2017b: 50]. The firms also operate in places without inspections regarding exposure to hazardous elements, such as excessive noise or carcinogenic substances (10-20\% of audited enterprises in the industrial sector in Poland) [PIP 2017: 39]. Workplaces often do not even meet standards of cleanliness [SUIP 2017c: 37], or are not properly labeled with regard to danger $-35 \%$ of audited construction sites in Poland lacked proper hazard communication [PIP 2017: 31].

Direct savings are made on personal OHS, training, and inspections. Enterprises were often found to operate tools and machines that do not meet current OHS or technical standards and that lack proper documentation, which makes them dangerous to operate [SUIP 2017c: 37]. Employees are often neither provided with occupational clothing nor given proper training on the machinery that they operate [SUIP 2017c: 37]. In Poland, 11\% of construction workers in audited construction sites operated machines such as excavators and feed lorries, etc. without qualifications or permits to do so [PIP 2017: 32]. The necessity to check to see if employees are medically fit for work is the second most common OHS infringement in Slovakia [Table 2 in the attachment to NIP 2017], and is relatively common in Poland as well [PIP 2017: 51, 56]. To lower OHS training and medical checkup costs, Polish enterprises often turn to civil law contracts, where the responsibility to comply with those requirements is placed on the employee [PIP 2017: 69]. This shows us an innovation-oriented activity.

\section{THE "SUPPLY" LEVEL - HOW AN INSTITUTIONAL FRAMEWORK ENCOURAGES INNOVATIVE PRACTICES}

According to the VoC approach, an institutional framework should encourage firms to engage in activities consistent with the principal logic of coordination [Deeg 2007; Hall, Soskice 2001]. For instance, strict labor law in CMEs increases the long-term orientation of employers and employees, and therefore promotes competition revolving around incremental innovations. Relaxed employment regulations among LMEs increase labor market flexibility and ease market reorientations, crucial for radical innovation. From the examples, we can also see that one of the purposes of labor law is to protect a particular type of competition.

In DMEs, firms aim at lowering labor costs by violating or circumventing statutory employment standards. An institutional framework promotes and eases "Mertonian" strategies, thus creating a field for innovative practices which lower labor costs, but also impacting the labor market in a more structural, broad way. 
First, there is the issue of the quality of legal regulations ${ }^{7}$. Employment regulations in DMEs often change ${ }^{8}$, which may make it difficult to keep up with the regulation (especially for the smaller firms) and - as shown in the previous section - they are often very inconsistent, especially with regard to boundaries between different types of contracts. Employment regulations in DMEs stipulate a huge variety of contracts on which work may be performed, but it is not clear when specific forms of contracts can legally be used, and when particular use constitutes a circumvention or violation of the regulation [Kahancová 2016; Martišková, Sedláková 2016; Meszmann 2016; Maciejewska, Mrozowicki 2016; Muszyński 2016; Grzebyk 2015]. When the law imposes imprecise obligations, one may expect that firms will choose solutions which are more beneficial from a financial point of view - non-standard contracts. Tax optimization is not necessarily limited to employers, since non-standard contracts may sometimes also be beneficial for employees who, in individual cases, may ask for them in order to receive a higher net wage [Williams 2015; Skowron-Mielnik, Wojtkowiak 2016].

Second, weak surveillance mechanisms allow for strategic violations and circumventions, since infringements in the area of employment regulation are not properly monitored and sanctioned. All CEECs are characterized by low coverage of collective agreements and weak trade unions (density around $10-15 \%$ in all CEECs) [Visser 2016]. Labor law surveillance in CEECs is very statist - with some exceptions (such as Polish social labor inspection) the principal agents guarding labor standards are the respective labor inspectorate bodies. At the same time, surveillance by the state is weak. The effectiveness of labor inspectorates (LI) is very low due to either formal regulations or bureaucratic practices.

TABLE 2. Sanctions for labor law violations in CEECs (2016 data)

\begin{tabular}{|l|c|c|c|c|}
\hline & Czechia & Hungary & Poland & Slovakia \\
\hline $\begin{array}{l}\text { Total number } \\
\text { of infringements } \\
\text { detected by LI }\end{array}$ & $\begin{array}{c}\text { no fewer than } \\
35,600^{\mathrm{a}}\end{array}$ & $13,487^{\mathrm{b}}$ & 80,029 & 41,935 \\
\hline $\begin{array}{l}\text { Total number } \\
\text { of fines }\end{array}$ & 3,921 & 1,676 & $\begin{array}{c}18,329(15,909 \text { by LI } \\
\text { and } 2,420 \text { by courts })\end{array}$ & 3,041 \\
\hline
\end{tabular}

I would like to thank the anonymous reviewer for this suggestion.

8 Between 2009 (which we can treat as the first year of the economic crisis in CEE) and July 2018 (when this paper is being finished), Polish Labor Code was amended 48 times, Czech - 33 times, and Slovak - 31 times. Hungarian Labor Code that went into force on 1 July 2012 was amended 10 times, as of July 2018. 


\begin{tabular}{|c|c|c|c|c|}
\hline & Czechia & Hungary & Poland & Slovakia \\
\hline $\begin{array}{l}\% \text { of detected } \\
\text { infringements } \\
\text { sanctioned with } \\
\text { fines }\end{array}$ & $\begin{array}{l}\text { Low to average } \\
11 \% \text { (max., } \\
\text { probably much } \\
\text { lower) }^{\mathrm{c}}\end{array}$ & $\begin{array}{c}\text { Average } \\
12.4 \%\end{array}$ & $\begin{array}{l}\text { High } \\
22.9 \%\end{array}$ & $\begin{array}{l}\text { Low } \\
7.3 \%\end{array}$ \\
\hline $\begin{array}{l}\text { Overall sum } \\
\text { of fines }\end{array}$ & $\begin{array}{c}\text { EUR } \sim 7.7 \mathrm{~m} \\
(\mathrm{CZK} \sim 198.1 \mathrm{~m})\end{array}$ & $\begin{array}{l}\text { EUR } \sim 0,75 \mathrm{~m} \\
(\mathrm{HUF} \sim 230 \mathrm{~m})\end{array}$ & $\begin{array}{c}\text { EUR } \sim 5.8 \mathrm{~m} \\
\text { (PLN } \sim 24 \mathrm{~m} \text { including } \\
\text { PLN } \sim 19 \mathrm{~m} \text { by inspec- } \\
\text { tors and PLN } \sim 5.7 \mathrm{~m} \\
\text { by courts) }\end{array}$ & EUR $\sim 7 \mathrm{~m}$ \\
\hline Average fine & $\begin{array}{c}\text { High } \\
\text { EUR } \sim 1,975 \\
(\mathrm{CZK} \sim 50,550)\end{array}$ & $\begin{array}{l}\text { Low } \\
\text { EUR } \sim 440 \\
\quad(\text { HUF } \\
\sim 138,000)\end{array}$ & $\begin{array}{c}\text { Low } \\
\text { EUR } \sim 285 \text { (PLN } \\
\sim 1,200 \text { ) by inspectors } \\
\text { EUR } \sim 570 \text { (PLN } \\
\sim 2,400 \text { ) by courts } \\
\end{array}$ & $\begin{array}{c}\text { High } \\
\text { EUR } \sim 2,285\end{array}$ \\
\hline $\begin{array}{l}\text { SMEs treated } \\
\text { softer for } \\
\text { violations }\end{array}$ & No information & $\begin{array}{l}\text { Yes (formally } \\
\text { established }^{\mathrm{d}} \text { ) }\end{array}$ & $\begin{array}{l}\text { Yes (administrative } \\
\text { recommendation }^{\mathrm{e}} \text { ) }\end{array}$ & $\begin{array}{l}\text { Yes (formally } \\
\text { establishedf) }\end{array}$ \\
\hline $\begin{array}{l}\text { First offenders } \\
\text { treated lightly } \\
\text { for violations }\end{array}$ & $\begin{array}{l}\text { Yes (informal } \\
\text { practice and } \\
\text { case lawg) }\end{array}$ & $\begin{array}{l}\text { Yes (formally } \\
\text { established }^{\mathrm{h}} \text { ) }\end{array}$ & $\begin{array}{l}\text { Yes (administrative } \\
\text { recommendation }^{\mathrm{i}} \text { ) }\end{array}$ & $\begin{array}{l}\text { Yes (indirectly } \\
\text { formally } \\
\text { established }{ }^{\mathrm{j}} \text { ) }\end{array}$ \\
\hline
\end{tabular}

a Please see footnote no 2 .

b Please note that the Hungarian data refers to the number of enterprises that committed labour law violations and were subject to fines, and not to the number of infringements subject to fines. Subsequently, the data in the table indicate the percentage of enterprises that committed labour law violations and were sanctioned.

c As indicated in footnote no 2, the number of overall infringements is probably much higher, and therefore the percentage of infringements sanctioned with fines is much lower. For instance, we have at our disposal data on the overall number of infringements from the Labour Inspectorate in the South Moravian and Zlin districts. The overall number of infringements there is 7,936 and the number of fines -444 , which would mean that only around $5.5 \%$ of all infringements were sanctioned financially [SUIP 2017c].

d Article 12/A of 2004 Act on Small and Medium-sized Enterprises and their Development.

e PIP 2017: 117ff.

f Article 19 point 6) letter b) of the Labour Inspection Act No 125/2006 Coll.

g SUIP 2017a: 19-20.

h Article 12/A of 2004 Act on Small and Medium-sized Enterprises and their Development. PIP 2017: 117ff.

j Article 19 point 6) letter d) Labour Inspection Act No 125/2006 Coll.

Source: SUIP 2017a; SUIP 2017b; NIP 2017; NGM 2017a; PIP 2017 (calculations are by author except for Polish average sanctions which is taken from PIP calculations) 
The table shows us four countries with some similarities and dissimilarities. In Czechia and Slovakia, a large proportion of infringements remain unpunished. However, when infringements are sanctioned, fines are relatively high - EUR 2,285 in Slovakia and EUR 2,450 in Czechia. In Hungary, over $12 \%$ of infringements are punished financially, but sanctions are relatively low - ca. EUR 440. Lastly, Poland is characterized as having a relatively higher propensity for the labor inspectors and courts to punish enterprises, with almost $23 \%$ of detected infringements sanctioned financially, but sanctions are very low - on average EUR 285 when the fine is levied by a labor inspector and EUR 570 when it is levied by a court, which is a rare occurrence. Considering the extent of savings that can be made on the labor law violations, rare or very low sanctions can allow firms to strategically violate certain types of provisions. For instance, the Labor Inspectorate report claims that enterprises in Poland very often consciously violate labor regulations thanks to low sanctions, which are calculated into the costs of conducting entrepreneurial activity [PIP 2017: 111]. We should note, however, that there are substantial differences in the overall amount of fines between Czechia and Slovakia on the one hand, and Hungary and Poland on the other. Overall, the amount of fines in Poland, with a population of $38 \mathrm{~m}$, is lower than in Slovakia with $5.5 \mathrm{~m}$. Sanctions in Hungary (population $9.8 \mathrm{~m}$ ) are over ten times lower than in Czechia (A population of $10.5 \mathrm{~m}$ ). This may suggest that the potential backlash to "Mertonian" adaptations is much more controllable and predictable in the case of firms in Poland and Hungary than in the case of firms in Czechia and Slovakia.

In CEECs, SMEs and first-time offenders are treated more leniently for violations. This may be a result of informal practices, administrative recommendations, case law or even - as in the case of Slovakia and Hungary - formal regulations. Slovak law states that what should be considered while calculating the fine is both the number of employees the enterprise hires as well as the incidental or systematic character of the infringement. Hungarian law explicitly states that - with some exceptions - in the case of the first infringement, small and medium enterprises are subject to a warning instead of a financial sanction. The reasoning for the Act claimed that the idea behind the provision was that the real goal of the law should be to educate and promote conformity and not "earn" off firms that violate the labor law; therefore, in the first case of infringement, a warning should be enough". As a result, in CEECs, mostly large enterprises and "recidivists" are fully exposed to labor law sanctions, which gives SMEs a big chance to explore

\footnotetext{
9 See: Hungarian Supreme Court (Kuria) judgement, no 2/2013 KMJE.
} 
labor law violations - not paying workers overtime pay, using undeclared work, and then eventually switching to formal employment if their first infringements are detected, etc. [NGM 2017b: 15].

Moreover, the number of audits and general effectiveness of institutions that monitor labor standards remain low. For instance, due to complicated administrative procedures, the length of the audit, and issues such as underfunding, the number of audits per inspector in CEECs is relatively low. While it is extremely rare for developed countries to have less than 100 audits per inspector per year [ILO 2011: 112-113], all CEECs drop below this level. Again, Czechia and Slovakia seem slightly more efficient in terms of employment surveillance than Hungary and Poland.

TABLE 3. Number of inspectors, audits, and inspections per inspector (2016 data)

\begin{tabular}{|l|c|c|c|c|}
\hline & Czechia & Hungary & Poland & Slovakia \\
\hline $\begin{array}{l}\text { Number } \\
\text { of inspectors }\end{array}$ & 496 & $400^{\mathrm{a}}$ & 1,703 & 320 \\
\hline $\begin{array}{l}\text { Total number } \\
\text { of audits }\end{array}$ & 29,627 & 17,869 & 80,029 & 28,084 \\
\hline $\begin{array}{l}\text { Number of audits } \\
\text { per inspector }\end{array}$ & $\sim 60$ & $\sim 45$ & $\sim 47$ & $\sim 87$ \\
\hline
\end{tabular}

a I was provided with this data by Hungarian Ministry for National Economy in a public access information request in December 2017.

Source: SUIP 2017a; NIP 2017; PIP 2017; NGM 2017a (calculations are by author).

We should also analyze here the broader implications that this structure of institutional framework means for coordination mechanisms. From a more structural point of view, labor law violations and circumventions also increase the bargaining power that employers have over workers, which obviously influences labor costs by limiting wage growth. Non-standard workers, especially the selfemployed, or workers whose rights are violated, are less likely to self-organize, i.e., join or establish trade unions. This can be due to a more elusive relationship with the enterprise (self-employed and civil law workers, as subcontractors, are less integrated with the staff than standard workers) or due to purely legal obstacles. In Hungary and Poland ${ }^{10}$, civil law workers and simplified employment

10 As of July 2018, self-employed and civil law workers in Poland are still deprived of the right to join and establish trade unions, even though a Constitutional Court judgement obliging the Parliament to establish such a law was issued in June 2015 (however, the legislative process is at an advanced stage). 
workers are deprived of the right to join and establish trade unions [Meszmann 2016: 10]. Furthermore, infringements and circumventions can be used to manipulate the workers, which negatively influences their bargaining power. For instance, in Poland, it is common that workers are at first given a non-standard contract and only after proving to be docile are they rewarded with a standard contract [Bednarski 2012].

Moreover, a macro perspective should be added. The spread of violations influences the orientations and competitive strategies of enterprises. The VoC approach shows that firms in specific political economies are motivated to focus on certain types of competition that are promoted and embedded within a larger institutional framework that creates institutional comparative advantages. Due to the shape of the institutional framework, the activity of firms in CMEs is centered around incremental innovations, whereas those in LMEs are around radical innovations. Since DMEs' comparative advantage is based on labor costs, firms functioning in this framework focus mostly on labor competitiveness. Labor law sets a certain standard that increases labor costs and decreases labor flexibility. Violating this standard can, therefore, decrease labor costs and increase employment flexibility, which results in an advantage over other firms in the most crucial element for the success within this framework - labor costs. Firms in DMEs that violate labor regulations seem to be aware of the competitive advantage that is provided by labor violations, which is the reason for the emergence of the multiple "innovative practices" described in the previous section. In a way, due to the role of low labor costs and multiple possibilities to lower them through violations, firms may compete by violating employment regulations. Gaining an economic advantage over the competition is explicitly cited by Czech employers to substantiate why they use bogus self-employment [Eurofound 2017: 7]. Anecdotal evidence from labor inspectorate reports also substantiates the claim that employers mostly violate the labor law to lower labor costs and gain an advantage over their competitors [PIP 2017: 28, 111; NGM 2017b: 15]. This is also partially substantiated by the data on the shadow economy and its impact on the general competition mechanisms - enterprises in CEECs believe that the shadow economy plays a crucial role in why certain enterprises gain an advantage over others [Rais, Klička, and Rod 2015; Global Compact Poland 2015: 23]. 


\section{"POLICY" LEVEL - POLICY DRIFTS AS EFFECTIVE PUBLIC POLICIES IN DMES}

As shown in the theoretical part, the fundamental problem of the VoC approach is the question of how rule makers may intervene in institutional frameworks to increase economic performance. In LMEs, this happens through "market-oriented" interventions such as liberalization, whereas in CMEs it is done through "coordinationoriented" actions such as supporting the self-governance of the economic agents.

Institutional frameworks in DMEs promote "Mertonian" actions aiming at circumventing or violating regulations. Considering the characteristics of the labor "cost innovations" undertaken, owing to the low effectiveness of an institutional framework, policymakers may promote those actions mainly through what could be called "policy drifts". Drift describes a political strategy where policymakers either consciously do not adapt maladjusted institutions, or indirectly create holes in the system that can be exploited to circumvent or violate formal regulations [Hacker 2004; Mahoney, Thelen 2009; Hacker, Thelen, Pierson 2013]. Drift, therefore, leads to formal institutions' losing the ability to structure the behavior of actors, who increasingly neglect it [Streeck, Thelen 2005].

It should be emphasized that massive and continuous non-compliance with employment regulations in CEECs takes place with at least some governmental approval or even "political cultivation" [term after: Streeck, Thelen 2005: 25]. Some examples were already provided above. Administrative recommendations influenced by formal law not to punish SMEs and first-time offenders for labor law iolations make it viable and possible for firms to consciously violate labor law. The fact that labor surveillance is weak, and infringements are either extremely rarely met with financial sanctions or fines are very low, also allows for the strategic use of circumventions and violations. Another specific example is creating and institutionalizing non-standard contracts as substitutes for standard contracts. To improve the economic situation after the crisis, the governments in CEECs implemented major formal changes to non-standard contracts, which, in fact, were intended to serve as alternatives for labor code contracts. Governments, in fact, promoted non-standard substitutes which were used to circumvent standard contracts, thus contributing to their declining significance. The Polish government enlarged the scope of use of fixed-term contracts and welcomed civil law contracts as alternatives to standard contracts [Czarzasty, Owczarek 2012; Muszyński 2016]. The Czech government extended the maximum length of fixed-term contracts, increased the number of hours which could be performed under civil law contracts, and extended the trial period for managerial positions 
[Martišková, Sedláková 2016]. The Slovak government extended the possibility to use fixed-term contracts [Kahancová 2016]. Hungary's 2012 Labor Code hugely incentivized the use of fixed-term and part-time contracts instead of open-ended and full-time workers [Meszmann 2016].

\section{CONCLUSIONS}

In order to explain the prevalence of labor law infringements among CEECs, the paper suggested integrating DME theory more deeply in the VoC approach. DME theory lacked an elaborated interpretation of how firms can creatively engage the institutional framework of dependent market economies in order to reap benefits. Moreover, it was unclear what actions governments in DMEs could undertake to enhance coordination mechanisms. I argued that those shortcomings were also related to a lack of an elaborated idea of innovation within DME theory.

Firms' strategies, the basic formal shape of the institutional framework, and public policies are closely linked, thus encouraging and incentivizing labor law infringements. This structure complements DMEs' institutional comparative advantage of lower labor costs. At the micro level ("demand level"), data on infringements show that circumventions and violations constitute a "Mertonian" type of innovative practice, enabling firms to lower labor costs and gain explicit financial gains. An institutional framework ("supply level") enables and encourages "Mertonian" adaptations intended to lower labor costs, due to the low quality of legal regulation (legal loopholes, blurred boundaries between different forms of contracts), and weak surveillance mechanisms (low sanctions, occasional controls). By enabling infringements, an institutional framework not only allowed for savings, but it also impacted broader coordination mechanisms: it increased the bargaining power of employers over workers, thus slowing wage growth, and it influenced competitive strategies of enterprises, creating incentives for firms to focus mostly on labor competitiveness. The paper also argued that policymakers in DMEs can influence coordination mechanisms by implementing drift policies. Drift policies increase the maladaptation of an institutional framework or create alternatives that undermine existing formal institutions, thus increasing the effectiveness of "Mertonian" innovation practices.

This leads us to the somewhat paradoxical conclusion that the element of DMEs' institutional comparative advantage used by firms for their benefit is precisely the institutional weakness that can be exploited in order to lower labor costs. This adds to our understanding of how many institutional deficiencies that exist in CEECs are reconciled with their relative economic success, as well as to 
the understanding of the governmental role in this process. A finding that governments in CEECs can intentionally promote institutional breakdowns is in line with the vast sociological and political literature that argues that policymakers in CEECs are prone to either encourage informal behaviours, or at least to accept them, mainly due to the underdevelopment of the rule of law and various political path-dependencies dating back to the communist period [see e.g., Staniszkis 1999; Federowicz 2004; Grzymala-Busse 2010; Bohle, Greskovits 2012; Jasiecki 2013]. Issues such as path dependency, lock-in effects, and the influence on other elements of an institutional framework, should be further examined.

\section{REFERENCES}

Amable Bruno. 2003. The diversity of modern capitalism. Oxford: Oxford University Press.

Bednarski Marek. 2012. Zatrudnienie na czas określony. Perspektywa pracodawców. In: Zatrudnienie na czas określony w polskiej gospodarce. Społeczne i ekonomiczne konsekwencje zjawiska, M. Bednarski, K.W. Frieske (eds.), 36-66. Warszawa: IPiSS.

Bluhm Katharina. 2010. "Theories of capitalism put to the test: introduction to a debate on central and eastern Europe". Historical Social Research/Historische Sozialforschung 35(2): 197-217.

BAG [Bundesamt für Güterverkehr]. 2017. BAG veröffentlicht Lkw-Maut-Ergebnisse der ersten 3 Quartale. Köln. https:/www.bag.bund.de/SharedDocs/Pressemitteilungen/ DE/2017/2017_12.html [access: 15.01.2018].

Bohle Dorothee, Béla Greskovits. 2012. Capitalist diversity on Europe’s periphery. Ithaca-London: Cornell University Press.

Casper Steven. 2010. The comparative institutional analysis of innovation: From industrial policy to the knowledge economy. In: The Oxford handbook of comparative institutional Analysis, G. Morgan, J.L. Campbell, C. Crouch, O.K. Pedersen, R. Whitley (eds.), 335-362. Oxford: Oxford University Press.

Czarzasty Jan, Dominik Owczarek. 2012. The economic crisis and social dialogue in Poland. Warsaw: Institute for Public Affairs.

Deeg Richard. 2007. "Institutional complementarity and change in capitalist systems". Journal of European Public Policy 14(4): 612-623.

Drahokoupil Jan, Martin Myant. 2015. Putting comparative capitalisms research in its place: varieties of capitalism in transition economies. In: New directions in comparative capitalisms research, M. Ebenau, I. Bruff, C. May (eds.), 155-171. London: Palgrave Macmillan.

Drahokoupil Jan, Martin Myant. 2016. Dependent capitalism and employment relations in East Central Europe. In: Labour and social transformation in Central and Eastern Europe: Europeanization and beyond, V. Delteil, V.N. Kirov (eds.), 42-59. London-New York: Routledge.

Drahokoupil Jan. 2009. Globalization and the state in Central and Eastern Europe: the politics of foreign direct investment. London-New York: Routledge.

Eurofound. 2017. Fraudulent contracting of work: Bogus self-employment [Czech Republic, Spain and UK]. Dublin: Eurofound.

Eurostat. 2017. Labour force survey. 
Federowicz Marek. 2004. Różnorodność kapitalizmu. Instytucjonalizm i doświadczenie zmiany ustrojowej po komunizmie. Warsaw: IFIS PAN.

Geissler Hana. 2012. New regulations aim to fight bogus self-employment. Eurofound. https:// www.eurofound.europa.eu/observatories/eurwork/articles/new-regulations-aim-to-fight-bogus-self-employment. [access: 15.01.2018].

Global Compact Poland. 2015. Przeciwdziałanie szarej strefie w Polsce. Warsaw: UN.

Goliaš Peter. 2014. Reforming non-standard contracts in Slovakia. INEKO.

Goraus-Tanska Karolina, Piotr Lewandowski. 2016. Minimum wage violation in Central and Eastern Europe. Bonn: Institute for the Study of Labor.

Grzebyk Piotr. 2015. Analiza orzecznictwa sadowego w sprawach o ustalenie istnienia stosunku pracy. Zatrudnienie pracownicze a zatrudnienie cywilnoprawne. Warszawa: Instytut Wymiaru Sprawiedliwości.

Grzymala-Busse Anna. 2010. „,The best laid plans: the impact of informal rules on formal institutions in transitional regimes". Studies in Comparative International Development 45(3): 311-333.

Hacker Jacob. 2004. "Privatizing risk without privatizing the welfare state: The hidden politics of social policy retrenchment in the United States". American Political Science Review 98(2): 243-260.

Hacker Jacob, Kathleen Thelen, Paul Pierson. 2013. Drift and conversion: Hidden faces of institutional change. Available at: http://ssrn.com/abstract=2303593 [access: 15.01.2018].

Hall, Peter A., David Soskice. 2001. An Introduction to Varieties of Capitalism. In: Varieties of capitalism: The institutional foundations of comparative advantage, P.A. Hall, D. Soskice (eds.), 1-68. Oxford: Oxford University Press.

ILO (International Labour Organisation). 2011. Labour administration and labour inspection. Geneva: ILO.

Jackson Gregory, Richard Deeg. 2008. "Comparing capitalisms: understanding institutional diversity and its implications for international business". Journal of International Business Studies 39: 540-561.

Jasiecki Krzysztof. 2013. Kapitalizm po polsku: między modernizacją a peryferiami Unii Europejskiej. Warszawa: Instytut Filozofii i Socjologii Polskiej Akademii Nauk.

Jasiecki Krzysztof. 2014. "Polityka publiczna wobec kapitału zagranicznego. Kapitalizm zależny?". Studia z Polityki Publicznej 4: 9-37.

Kahancová Marta. 2016. The rise of the dual labour market: fighting precarious employment in the new member states through industrial relations (PRECARIR) Country report: Slovakia. Bratislava: CELSI.

Kamińska Agnieszka, Piotr Lewandowski. 2015. The effects of minimum wage on a labour market with high temporary employment. Warsaw: IBS.

Kristensen Peter H., Jonathan Zeitlin. 2005. Local players in global games: The strategic constitution of a multinational corporation. Oxford: Oxford University Press.

Lehrer Mark. 2001. Macro-varieties of capitalism and micro-varieties of strategic management in European airlines. In: Varieties of Capitalism: The Institutional Foundations of Comparative Advantage, P.A. Hall, D. Soskice (eds.), 361-386. Oxford: Oxford University Press.

Maciejewska Malgorzata, Adam Mrozowicki. 2016. The rise of the dual labour market: fighting precarious employment in the new member states through industrial relations (PRECARIR). Poland: Country report. Bratislava: CELSI. 
Mahoney James, Kathleen Thelen. 2009. A theory of gradual institutional change. In: Explaining institutional change: ambiguity, agency, and power, J. Mahoney, K. Thelen (eds.), 1-37. New York: Cambridge University Press.

Martišková Monika, Mária Sedláková. 2016. The rise of the dual labour market: fighting precarious employment in the new member states through industrial relations (PRECARIR). The case of Czechia. Bratislava: CELSI.

Merton Robert K. 1968. Social theory and social structure (1968 enlarged edition). New York: The Free Press.

Meszmann Tibor. 2016. Country report: Hungary PRECARIR: The rise of the dual labour market: fighting precarious employment in the new member states through industrial relations. Bratislava: CELSI.

Muszyński Karol. 2016. "Factors behind the growth of civil law contracts as employment contracts in Poland - a study of labour law violations". Prakseologia 158, 323-359.

NIP (Národný inšpektorát práce). 2017. Správa o stave ochrany práce a o činnosti orgánov štátnej správy v oblasti inšpekcie práce za rok 2016. Košice

NGM (Nemzetgazdasági Minisztérium Munkavédelmi Főosztály). 2017a. A munkaügyi ellenörzés tapasztalatai [2016. év]. Budapest.

NGM (Nemzetgazdasági Minisztérium Munkavédelmi Főosztály). 2017b. Összefoglaló jelentés a munkavállalók jogviszonyának rendezettsége érdekében a foglalkoztatásra vonatkozó alapvető szabályok érvényre juttatására irányuló akcióellenőrzéséről [2017. június 19. - július 7.]. Budapest.

Nölke Andreas, Arjan Vliegenthart. 2009. "Enlarging the varieties of capitalism: The emergence of dependent market economies in East Central Europe". World Politics 61(4): 670-702.

Nölke Andreas. 2011. Transnational economic order and national economic institutions: comparative capitalism meets international political economy. Cologne: Max Planck Institute for the Study of Societies.

PIP (Państwowa Inspekcja Pracy). 2017. Sprawozdanie z działalności Państwowej Inspekcji Pracy w 2016 r. Warszawa.

PIP (Państwowa Inspekcja Pracy). 2016. Sprawozdanie z działalności Państwowej Inspekcji Pracy $w 2015$ r. Warszawa.

Rais Jonáš, Ondřej Klička, Aleš Rod. 2015. Stínová ekonomika v České republice. Praha: Cetrum ekonomických a tržních analýz.

Schumpeter Joseph A. 1934(2008). The theory of economic development: An inquiry into profits, capital, credit, interest and the business cycle. New Brunswick-London: Transaction Publishers.

Skowron-Mielnik Beata, Grzegorz Wojtkowiak. 2016. "Formy zatrudnienia - analiza elastyczności pracowników”. Organizacja i kierowanie 3(173): 81-98.

Staniszkis Jadwiga. 1999. Post-communism: The emerging enigma. Warsaw: Institute of Political Studies, Polish Academy of Sciences.

SUIP (Státní úr̆ad inspekce prace). 2017a. Ročni souhrnné zprávy o výsledcích kontrolních akcí provedených inspekci práce. Roční souhrnná zpráva o výsledcich kontrolních akcí provedených inspekcí za rok 2016. Oprava

SUIP (Státní úrad inspekce prace). 2017b. Zpráva o činnosti Státního úřadu inspekce práce za rok 2016.

SUIP (Státní úrad inspekce prace). 2017c. Zpráva o činnosti Oblastního inspektorátu práce pro Jihomoravský kraj a Zlínský kraj za rok 2016. Brno. 
Streeck Wolfgang. 2004. Taking uncertainty seriously: Complementarity as a moving target. In: Workshops/Oesterreichische Nationalbank, Eurosystem: proceedings of OeNB workshops, 101-115. Oesterreichische Nationalbank.

Streeck Wolfgang. 2009. Re-forming capitalism. Oxford: Oxford University Press.

Streeck Wolfgang, Kathleen Thelen. 2005. Introduction: Institutional change in advanced political economies. In: Beyond continuity. institutional change in advanced political economies, W. Streeck, K. Thelen (eds.), 1-39. Oxford: Oxford University Press.

Williams Colin C., Ioana A. Horodnic, Jan Windebank. 2015. "Explaining participation in the informal economy: an institutional incongruence perspective". International Sociology 30(3): 294-313.

Williams Colin C. 2015. "Evaluating cross-national variations in envelope wage payments in East-Central Europe", Economic and Industrial Democracy 36(2): 283-303.

Witt Michael A., Gregory Jackson. 2016. "Varieties of capitalism and institutional comparative advantage: A test and reinterpretation". Journal of International Business Studies 47(7): $778-806$.

Visser Jelle. 2016. ICTWSS data base. version 5.1. Amsterdam: Amsterdam Institute for Advanced Labour Studies.

Zaccaria Márton Leó. 2015. "The changing concept of employment: The special connection between labour law and civil law in Hungary". Warsaw Forum of Economic Sociology 6:1(11): 131-139.

Karol Muszyński

\section{NARUSZENIA PRAWA PRACY JAKO INNOWACJE W PAŃSTWACH EUROPY ŚRODKOWO-WSCHODNIEJ}

\section{Streszczenie}

Artykuł analizuje dane wtórne pochodzące z inspekcji pracy Czech, Polski, Słowacji i Węgier (państw Europy Środkowo-Wschodniej-EŚW) i argumentuje, że popularność i struktura naruszeń prawa pracy powinna być tłumaczona przez fakt, że naruszenia prawa pracy są specyficznymi formami adaptacji/innowacji dokonywanymi przez firmy w państwach EŚSW, nakierowanymi na obniżanie kosztów pracy i uelastycznianie stosunków zatrudnienia. Artykuł wykorzystuje teorię gospodarki rynkowej zależnej pochodzącą z ujęcia różnorodności kapitalizmu (varieties of capitalism). Główna przewaga komparatywna zależnych gospodarek rynkowych leży w niskich kosztach pracy. Rozpowszechnienie i najpopularniejsze formy naruszeń wskazują że firmy wykorzystują naruszenia prawa pracy w sposób kreatywny, aby wyostrzyć swoją przewagę konkurencyjną. Umożliwia to nieefektywny system nadzoru przestrzegania prawa pracy. Możliwości obchodzenia i naruszenia regulacji zatrudnienia powinny być traktowane jako elementy instytucjonalnej przewagi komparatywnej państw EŚW. Artykuł sugeruje również, że rządy państw EWŚ częściowo promują naruszenia prawa pracy poprzez ,polityki dryfu”.

Słowa kluczowe: naruszenia prawa pracy, zależna gospodarka rynkowa, różnorodność kapitalizmu, innowacja, Europa Środkowo-Wschodnia 